\title{
SUCCESSION MODEL WITH CORTNEPHORUS CANESCENS IN ABANDONED SANDY FIELDS (W SLOVAKIA)
}

\author{
Milan VALACHOVIČ ${ }^{1}$
}

\begin{abstract}
The succession of vegetation on acidic sandy fields after abandonment was studied and obtained results were compared with similar data from eastern part of Europe. The vegetation changes head towards oligotrophic Corynephorus-grasslands, because nutrients from the upper layer of soils are gradually washed out. Dry, occasionally blowing sand enables the growth of psammophytes very well. The paper compares the succession models on abandoned sandy fields, and semi-natural acidic sandy dunes in western part of Slovakia, southern Moravia, Hungary and Croatia. In spite of amazing similarities, some differences are displayed using spectra of life forms and presentation of weeds.
\end{abstract}

Keywords: arable land, inland sand dunes, weed, Corynephorion, Borská nížina Lowland.

\section{Izvleček:}

Proučevali smo sukcesijo vegetacije na opuščenih kislih peščenih poljih in primerjali rezultate s podobnimi podatki iz vzhodne Evrope. Spremembe vegetacije so usmerjene proti oligotrofnim traviščem z vrsto Corynephorus, saj se hranila postopomo izperejo iz zgornjih talnih plasti. Suh pesek, ki ga občasno prinese veter omogoča uspevanje psamofitom. $V$ članku smo primerjali sukcesijske modele na opuščenih peščenih poljih in polnaravnih kislih peščenih Dinah v zahodnem delu Slovaške, južne Moravske, Madžarske in Hrvaške. Kljub veliki podobnosti smo izpostavili določene razlike s spektrom življenskih oblik in prisotnostjo plevelnih vrst. Ključne besede: obdelana tla, celinske peščene dine, pleveli, Corynephorion, Borská nížina.

\section{INTRODUCTION}

The Corynephorus-grassland represents widespread pioneer vegetation on active mobile dunes along the exposed Atlantic coasts from Portugal to Denmark. It occur regularly along the southern Baltic Sea (Hultén \& Fries 1986: map 342) and decline as inland sand dune grasslands in the Central and Eastern European lowlands (Rychnovská 1963, Hršak 2004, Lájer 2004). The natural Corynephorus-grassland prefers acidic sands, but the particular species Corynephorus canescens occurs also on neutral or slightly basic dunes. For a growth of $C$. canescens is much more important open sandy substratum which is unstable, than accurate $\mathrm{pH}$ value, because this grass can auton- omously regulate the soil $\mathrm{pH}$ by its root system (Rychnovská 1963).

Beside dominant Corynephorus, another psammophytes with constant frequency are present, such as Acetosella vulgaris, Agrostis tenuis, A. vinealis, Hypochoeris radicata, Fasione montana, Logfia minima, Pilosella officinarum, Spergula morisonii, Teesdalia nudicaulis. This species assemblage well defines the dry acidophilous and nutrient-poor plant communities of the alliance Corynephorion canescentis Klika 1931 in larger European region (cf. Korneck 1978, p. 32, Dengler 2004). Some taxa with atlantic and subatlantic distribution, e.g. $\mathrm{Am}$ mophila arenaria or Carex arenaria differ west European stands from those occurred more eastern, but generally, the species composition of alliance

\footnotetext{
${ }^{1}$ Institute of Botany, Slovak Academy of Sciences, Dúbravská cesta 9, SK-845 23 Bratislava, Slovak Republic, e-mail: milan.valachovic(a)savba.sk
} 
is conspicuously uniform. This fact is recently well known and achieved by analyses based on large data from whole Europe (cf. Dörsing 2008).

Succession in abandoned fields and sandy areas has been investigated in numerous older studies (e.g. Prach 1985, Tilman 1987, Faliński et al. 1993) but is still very attractive for recent investigations (e.g. Putten et al. 2000, Csecserits \& Rédei 2001, Deng 2001, Ejrnæs et al. 2003, 2008, Koubková 2007, Török et al. 2008). The secondary succession on sandy soils obviously heads towards pine forest communities (Prach et al. 1993), but in special situation gives a chance for possible renaturalization of abandoned fields towards sandy semi-natural grasslands. A lower attention was given to the stands, where the sandy vegetation was fully destroyed, and for longer time managed as crop fields.

The aim of the paper is (i) to describe processes of succession on sandy soils, partly on natural dunes, but predominately on secondary stands; and (ii) to compare some succession models, known from eastern part of Europe with situation in abandoned fields in Slovakia.

\section{MATERIAL AND METHODS}

A total of 21 phytosociological relevés were carried out in the Borská nížina Lowland, equally from abandoned fields (10 rels.) as well as near natural dunes (11 rels.) in accordance of the Braun-Blanquet approach. The relevés were entered to the Turboveg database (Hennekens \& Schaminée 2001) and classified using modified TWINSPAN classification (Hill 1979, Roleček et al. 2009) and carried out by using JUICE software (Tichý 2002). All imput data are stored in Central database at the Institute of Botany (http://ibot. sav.sk/cdf). The final table depicts result of comparison of 52 relevés with similar stands found in East European regions (Hršak 2004, Lájer 2004, Koubková 2007), and with earlier stadium from the similar localities (Májeková 2005). The sorting of taxa to group of psammophytes and weeds in large extends follows index prepared by Jurko (1990). The spectra of life forms were calculated according this source as well. The abbreviations - $\mathrm{T}$ (therophytes = annuals and bienniales), $\mathrm{H}$ (hemicryptophytes), G (geophytes), C (chamaephytes), $\mathrm{P}$ (phanerophytes), M (mosses), and L (lichens). The nomenclature of plant species follows Marhold \& Hindák (1998).

\section{RESULTS}

The TWINSPAN classification separates in the first step the relevés from abandoned crop fields and group of those stands, which were under human impact but without agronomical and agrochemical procedures. While the first group (column A-B in Table 1) represents the development after abandonment of crop fields, the next three columns depict the succession on mechanically disturbed sandy areas. The fertilization and cultivation of fields in the past is manifested by presence of numerous weeds, e.g. Anthemis ruthenica, Conyza canadensis, Digitaria sanguinalis and many others. Especially in the earlier phases after abandonment, the fields are covered by nitrogen demanding plants, such as Agrostis gigantea, Chenopodium album, Crepis tectorum, Elytrigia repens or Echium vulgare, later the nutrients are rather quickly and easily wash out and the abundance of weeds changed in favour of more oligotrophic weeds, such as Agrostis capillaris, Digitaria sanguinalis, Trifolium arvense etc. (see column B in Table 1). The dry sand on the upper layer of soil prefers psammophytes. The Corynephorus canescens, together with shallow rooted therophytes, such as Logfia minima, Spergula morisonii, Teesdalia nudicaulis, Veronica dilenii, occupied the washed sand, but the nutrients in the deeper layer of soils give a sufficient conditions for growth of some weeds, like Hypochoeris radicata. The percentage of therophytes in column A is conspicuously high (59\%, see Figure 1, 2).

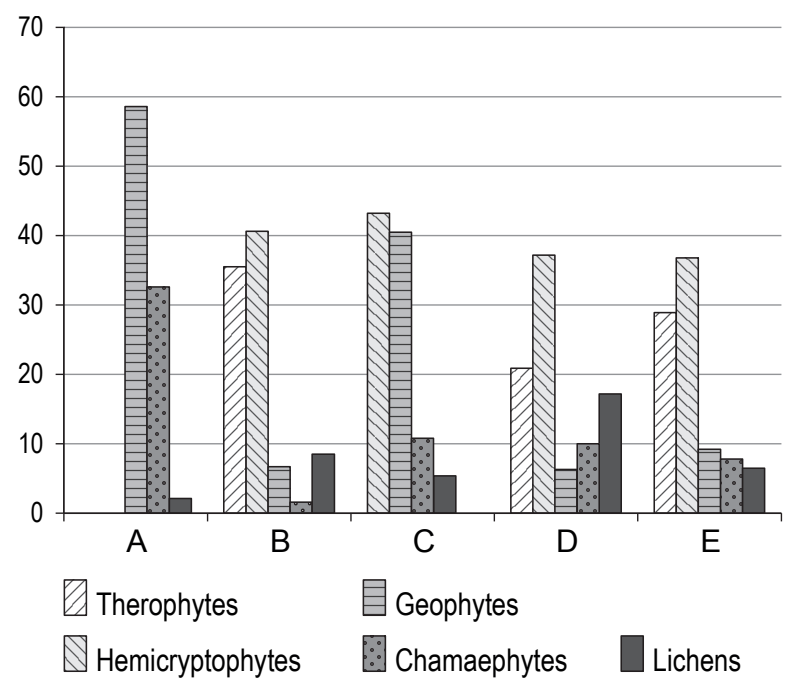

Figure 1: Percentage spectra of selected life forms in columns A-E.

Slika 1: Spekter izbranih življenskih oblik v odstotkih v stolpcih A-E. 




Figure 2: Weed Echium vulgare is replaced by oligotrophic Jasione montana and Logfia minima.

Slika 2: Plevel Echium vulgare nadomestita oligotrofni vrsti Jasione montana in Logfia minima.

The succession on open sandy dunes started obviously with acidophilous mosses - Polytrichum piliferum and lichens of the genus Cladonia. This model on the abandoned fields was not observed. Only sporadic were found lichens, often the Cladonia fimbriata. The result is partially misrepresented, because in some published data the cryptogamic flora has been overlooked (cf. Láyer 2004, column C, in Table 1).

In the column $\mathrm{D}$ are associated data from military grounds and ranges in Moravia and Slovakia, where traditionally absent agronomical interventions, but large areas (several hectares) are under extensive disturbance due military activities. The number of psammophytes here is much

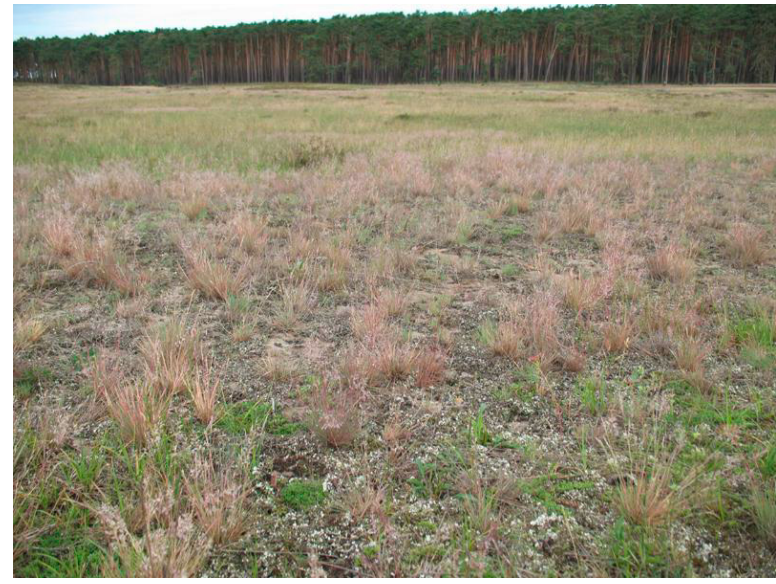

Figure 3: Corynephorus-grasslands in military range near Malacky, Krížnica.

Slika 3: Travišča z vrsto Corynephorus na vojaškem vadbišču pri naselju Malacky, Krížnica. higher and positive correlate with size of area and availability of propagules from neighbouring habitats (sandy grasslands and pine forests of $D i$ crano-Pinion alliance). Here is also high percentage of lichens in the relevés, 17\% (Figure 1), while the role of therophytes is suppressed (Figure 3).

A last column (E) differentiates species like Artemisia campestris, Carex praecox, Tithymalus cyparissias, and Festuca vaginata, all plants typical for sandy soils with neutral or slightly basiphilous reaction.

\section{DISCUSSION}

\section{Natural (near-natural) stands on sandy dunes}

The natural pioneer communities from the alliance Corynephorion canescentis are generally poor in vascular plants but rich in lichens, primarily of the genus Cladonia (Table 1, Figure 4). The floristic composition of herb layer is conspicuously uniform in whole area of its distribution. Among initial components of natural succession belongs mostly Spergula morisonii, Teesdalia nudicaulis, Veronica dilenii (cf. Juśkiewicz-Swaczyna 2009); in Eastern Europe also Thymus serpyllum (Chytrý 2007). Stands of Corynephorus-grasslands are obviously in this region named like separate association Thymo angustifolii-Corynephoretum canescentis Krippel 1954 and more dense grasslands than as the Festuco dominii-Corynephoretum Borhidi (1958) 1996. These are differentiated by Pannonian or continental species such as Carex ericetorum, Dianthus armeriastrum, D. serotinus,

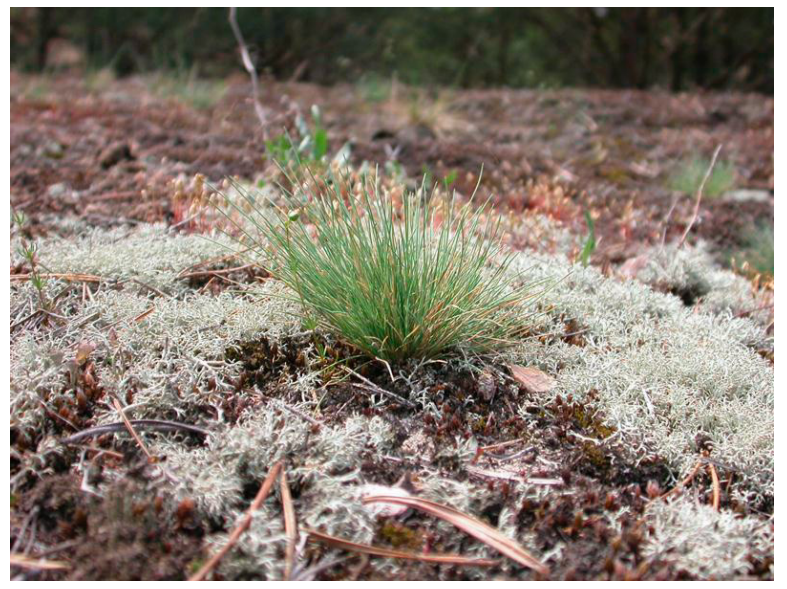

Figure 4: Corynephorus canescens growing in lichen carpet. Figure 4: Vrsta Corynephorus canescens uspeva na preprogi lišajev. 
Festuca vaginata subsp. dominii, Thymus serpyllum subsp. angustifolius, Veronica dillenii, Viola kitaibeliana and some others taxa (cf. Hršak 2004, Lájer 2004).

Vicherek (1972) documented the easternmost occurrence of such sand dunes steppes near Kiev (Ukraine), where the taxon Spergula morisonii is very rare; therefore these stands were associated to the Veronico dillenii-Corynephoretum Passarge 1960, which Vicherek considered as subcontinental vicariate association.

In recent studies (Chytrý 2007, Dörsing 2008, Juśkiewicz-Swaczyna 2009) the authors unified all stands, formerly described under the various names, into one association, the Corniculario aculeatae-Corynephoretum canescentis Steffen 1931 (Syn.: Spergulo morisonii-Corynephoretum canescentis R. Tx. (1928) 1955; Spergulo vernalisCorynephoretum canescentis R. Tx. (1928) Libbert 1933) and certain differentiation lies only on level of subassociations (Dörsing l.c.), variants or geographical races (Juśkiewicz-Swaczyna l.c.).

\section{Secondary stands on sandy fields}

The secondary grasslands with dominance of Corynephorus, sporadically developed on abandoned crop-fields after several years, showed differences against the above discussed stands of the Corniculario aculeatae-Corynephoretum canescentis association.

There are noticeable differences between habitats, which were ploughed, and then after 2 or 3 years afforested again by pine trees, or which were deforested, and for longer time exploited as crop-fields. As an example of succession on young pine plantings can be emphasized study by Šomšák (1976). He observed fallows on sandy soils in Borská nížina lowland and described than typical plant community Setario viridis-Erigeronetum Šomšák 1976. These stands are characterized by dominance of many weeds, like Conyza canadensis, Agrostis tenuis, Setaria viridis, Carex hirta, Apera spica-venti combined with lower presence by psammophytes such as Corynephorus canescens, Festuca vaginata subsp. dominii, and Logfia arvensis.

22 years long succession on abandoned sandy fields in Denmark studied Deng (2001). According his observation the annual weeds fade out as first (during 3-5 years) and Fasione montana and Acetosella vulgaris became dominant, slowly supplement with persistent perennials such as Pilosella officinarum. The Corynephorus canescens grows

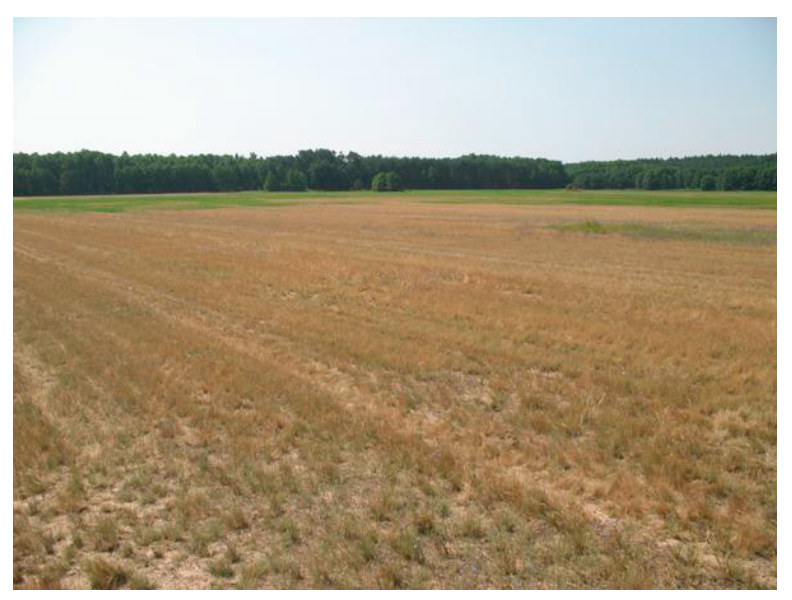

Figure 5: Abandoned field near Studienka with psammophyte vegetation.

Slika 5: Opuščena polja pri naselju Studienka s psamofitsko vegetacijo.

generally in this field very sparsely and after 12 years completely disappeared and whole field returned to Calluna vulgaris heathland. Faliński et al. (1993) studied vegetation dynamic on the abandoned sandy farmlands during secondary succession in Poland. The pioneer phase of vegetation after 2-3 years of the abandonment represent weed plants such as Digitaria ischaemum, Spergula arvensis accompanied by herbaceous perennials, among which psammophytes prevail - Jasione montana, Helichrysum arenarium, Hieracium pilosella, Hypericum perforatum, Hypochoeris radicata, Acetosella vulgaris, Solidago virgaurea, etc. The occurrence of psammophilous grass Corynephorus canescens as well as therophytes like Logfia minima is also characteristic (Figure 5).

The floristic correspondence with abandoned fields in Borská nížina lowland here is remarkable. The phase with funiperus communis (cf. Faliński et al. 1993) is not common in our study site, but final phase to stable pine forests after more than 100 years after the field abandonment should by one alternative also in Slovakia, but required to stop human impact to the fields (artificial forestation, repeated transformation into crop-fields, urbanization, etc.) for so long time.

\section{Succession models}

Typical succession model on natural acidic sandy dunes is generally described as (a) phase with open, shifting sand (dominate mosses and lichens), practically without vascular plants except the first tuft of grass Corynephorus canescens, (b) phase of dry grasslands with psammophytes 
such as Pilosella officinarum fasione montana, etc., (c) phase of closed grasslands with dominate Festuca sp. div., and (d) development towards Calluna vulgaris-heathland or direct to various oak pine forests. The primary succession is relatively slow. Small-scale disturbances (anthills, molehills, and holes) keep the process of succession towards sand grasslands in equilibrium for longer time (Jentsch et al. 2002, Tschöpe \& Tielbörger 2010).

Different situation is on sandy fields. Accumulation of organic matter gives gradually the opportunity for more demanding plants and onset of next phases with various nitrophilous and mesophilous plants (Ejrnæs et al. 2003). Very frequent situation is that fields are attack by rather specialized invasive aliens, in first stage annuals, herbaceous weeds and neophytes already present in the seed bank, latter also by persistent perennials (Van der Putten et al. 2000) and finally by alien woody species, such as Acer negundo and Robinia pseudoacacia (Pyšek et al. 1998). Hršak (2004) found direct relation between accumulation of organic matter and nutrients and changes in floristic pattern on sandy dunes in Croatia. Starting plants, like Corynephorus canescens and Festuca vaginata are replaced by Calamagrostis epigeios, Conyza canadensis, Oenothera biennis, Solidago gigantea, and shrubby Sambucus nigra. Very similar succession model is common also in our study area.

In southern Moravia Koubková (2007) investigated floristic variability and secondary succession in sandy vegetation on disturbed open sands after three decades, when J. Vicherek started study this vegetation. The results showed that soil $\mathrm{pH}$ did not change markedly, but the number of species with affinity to nutrients, soil moisture and neutral reaction (in sense to Ellenberg indication values) increased.

Secondary succession on abandoned fields with tendency to return toward more or less natural or near-natural vegetation is not typical phenomenon. Nevertheless, on sandy fields, where the low amount of nutrients eliminate demanding ruderal species during 10 years after abandonment (Csecserits \& Rédei 2001) the succession model head towards higher abundance of psammophytes. The nutrient poor soils support sand specialists and pioneer species of the open dunes, such as Spergula morissonii and others. The abandonment of fields with nutrient poor soils may lead to the formation of semi-natural grasslands, especially in situation, when prop- agules in seed bank or from neighbouring habitats are present (cf. Ejrnæs et al. 2008, Šefferová Stanová et al. 2011). Appropriate management on similar stands give a chance to create conditions for recover of rare plant populations and Natura 2000 habitats typical for acidophilous open sandy dunes, such as 2340 - Pannonic inland dunes, and 6260 - Pannonic sand steppes (Stanová \& Valachovič 2002).

\section{ACKNOWLEDGEMENT}

The author acknowledges to specialist for kindly determination of some hardly distinguishable taxa, P. Šmarda (Festuca), M. Peniašteková (Scleranthus), I. Pišút and A. Dingová (Cladonia). The research was supported from the Grant Agency of Slovak Academy of Sciences VEGA No. 0181 (Dynamics and succesion of grassland vegetation) and VEGA No. 0672 (Diversity changes in neighbouring zones with agrocoenoses).

\section{REFERENCES}

Csecserits, A. \& Rédei, T. 2001: Secondary succession on sandy old-fields in Hungary. Applied Vegetation Science 4: 63-74.

Deng, H.J. 2001: Succession from farmland to heathland: a case for conservation of nature and historic farming methods. Biological Conservation 97: 319-330.

Dengler, J. 2004: 21. Klasse: Koelerio-Corynephoretea Klika in Klika et V. Novák 1941 Sandtrockenrasen und Felsgrusfluren von der submeridionalen bis zur borealen Zone. In: Berg, C., Dengler, J., Abdank, A. \& Isermann, M. (eds), Die Pflanzengesellschaften Mecklenburg-Vorpommerns und ihre Gefährdung - Textband. Landesamt f. Umwelt, Naturschutz und Geologie Mecklenburg-Vorpommern. Weissdorn-Verlag Jena, pp. 301-326

Dörsing, M. 2008: Classification of Corynephorion vegetation. Abstracts and excursion guides. 17th International Workshop European Vegetation Survey, Brno, 1-5 May 2008.

Ejrnæs, R., Hansen, D.N. \& Aude, E. 2003: Changing course of secondary succession in abandoned sandy fields. Biological Conservation 109: 343-350.

Ejrnæs, R., Liira, J., Poulsen, R.S. \& Nygaard B. 2008: When has an abandoned field become a 
semi-natural grassland or heathland? Environmental Management 42: 707-716.

Faliński, J.B., Cieśliński, S. \& Czyżewska, K. 1993. Dynamic-floristic atlas of Jelonka Reserve and adjacent areas. Distribution of vascular plant species, bryophytes and lichens on the abandoned farmlands during secondary succession [Atlas dynamiczno-florystyczny Rezerwatu Jelonka i przyleglych obszarów. Rozmieszczenie gatunkow roslin naczyniowych, mszakow i porostów na nieuzytkach porolnych podlegajacych sukcesji wtórnej]. Phytocoenosis, Vol. 5 (N.S.), Suppl. Cartogr. Geobot. 3, Bialowieza Geobotanical Station, Warszawa-Bialowieza. 139 pp.

Hill, M.O., 1979: TWINSPAN - A Fortran program for arranging multivariate data in an ordered two-way table by classification of the individuals and attributes. Cornell Univ. Ithaca. NY.

Hršak, V., 2004: Vegetation succession and soil gradients on inland sand dunes. Ekológia, Bratislava 23: 24-39.

Hultén, E. \& Fries, M., 1986: Atlas of North European vascular plants: north of the Tropic of Cancer, Vol. 1., map. 342. Koeltz Scientific Books, Kőnigstein.

Jentsch, A., Friedrich, S., Beyschlag, W. \& Nezadal, W., 2002: Significance of ant and rabbit disturbance for seedling establishment in dry acidic grasslands dominated by Corynephorus canescens. Phytocoenologia 32: 553-580.

Jurko, A., 1990: Ekologické a socioekonomické hodnotenie vegetácie. Príroda. 195 pp.

Juśkiewicz-Swaczyna, B. 2009: The psammophilous grassland community Corniculario aculeatae-Corynephoretum canescentis in the Masurian Lake District (NE Poland). Tuexenia 29: 391-408.

Korneck, D. 1978: Corynephoretalia. In: Oberdorfer, E. (ed.), Süddeutsche Pflanzengesellschaften. Teil II. 2. Aufl. Gustav Fischer Verlag. Stuttgart - New York, pp. 31-45.

Koubková T., 2007: Nelesní vegetace písků na Hodonínsku a její změny po třech desetiletích. [Non-forest vegetation of the sand area near Hodonín, Czech Republic and its changes after three decades]. Diplom. Theses, Masaryk Univ. Brno. 72 pp.

Lájer, K. 2004: A rejtőke (Teesdalia nudicaulis) előfordulasa és a Bolső-somogyi ezüstperjés gyepek mai állapota. [The occurrence of Shepherd's Cress (Teesdalia nudicaulis) and the recent status of Grey Hair-grasslands in BolsőSomogy]. Somogyi Múzeumok Közleményei 16: $257-264$.

Májeková, J. 2005: Flóra a vegetácia na poliach a úhoroch Borskej nížiny. Diplom. Theses, PríFUK Bratislava.

Marhold, K. \& Hindák, F. 1998: Checklist of nonvascular and vascular plants of Slovakia. Veda, Bratislava, 687 pp.

Prach, K. 1985: Succession of vegetation in abandoned fields in Finland. Annales Botanici Fennnici 22: 307-314.

Prach, K., Fanta, J., Lukešová, A. \& Liška, J. 1993: De ontwikkeling van de vegetatie op stuifzand van de Veluwe. Gorteria 19: 73-79.

Pyšek, P., Prach, K. \& Mandák, B. 1998: Invasions of alien plants into habitats of Central European landscape: An historical pattern. In: Starfinger, U., Edwards, K., Kowarik I., Williarnsorz, M. eds, Plant Invasions: Ecological Mechanisms and Human Responses, Backhuys Publ., Leiden, The Netherlands, pp. 23-32.

Roleček J., Tichý L., Zelený D. \& Chytrý M. 2009: Modified TWINSPAN classification in which the hierarchy respects cluster heterogeneity. Journal of Vegetation Science 20: 596-602.

Rychnovská, M. 1963: An outpost site of Corynephorus canescens in the region between the Danube and the Tisza and its causal explanation. Acta Biologica Hungarica 14, 1: 57-66.

Stanová, V. \& Valachovič, M., eds. 2002: Katalóg biotopov Slovenska. DAPHNE - Inštitút aplikovanej ekológie, Bratislava. 225 pp.

Šefferová Stanová, V., Valachovič, M. \& Janák, M. 2011: Manažmentový model pre viate piesky. DAPHNE - Inštitút aplikovanej ekológie a Botanický ústav SAV, Bratislava (msc.).

Šomšák, L. 1976: Fytocenózy borovicových kultúr a rúbanísk viatych pieskov na Záhorskej nížine [Phytocoenoses of pine cultures and felled areas on drifting sands of the plain Záhorská nížina]. Biológia, Bratislava 31 (4): 241-251.

Tichý, L. 2002: JUICE, software for vegetation classification. Journal of Vegetation Science, 13: 451-453.

Tilman, D. 1987: Secondary succession and the pattern of plant dminance along experimental nitrogen gradients. Ecological Monographs 57: 189-214.

Török, P., Matus, G., Papp, M. \& Tóthmérész, B. 2008: Secondary succession in overgrazed Pannonian sandy grasslands. Preslia 80: 73-85. 
Tschöpe, O. \& Tielbörger, K. 2010: The role of successional stage and small-scale disturbance for establishment of pioneer grass Corynephorus canescens. Applied Vegetation Science 13: 326-335.

Van der Putten, W.H., Mortimer, S.R., Hedlund, K., Van Dijk, C., Brown, V.K., Lepš, J., Rodruguez-Barrueco, C., Roy, J., Diaz Len, T.A., Gormsen, D., Korthals, G.W., Lavorel, S., Santa Regina, I. \& Šmilauer, P. 2000: Plant species diversity as a driver of early succession in abandoned fields: a multi-site approach. Oecologia 124: 91-99.

Vicherek, J. 1972: Die Sandpflanzengesellschaften des unteren und mittleren Dnjeprstromgebietes (die Ukraine). Folia Geobotanica et Phytotaxonomica 7: 9-46.

\section{APPENDIX}

\section{Table heads:}

Column A, 6 rels., all by Májeková 2005 (orig. tab./rel.: 12/23, 12/24, 13/3, 12/25, 12/28, 12/27, made during years 2003-2004, on abandoned fields N from Studienka village, Borská nížina Lowland. Column B, 13 rels., 3 rels. (27-29) Májeková 2005 (orig. tab./rel.:7/1, 8/1, 13/6, all on abandoned fields $\mathrm{N}$ from Studienka village + 10 rels. made by author during year 2010 - number in table, date (yymmdd), plot $\left(\mathrm{m}^{2}\right)$, altitude (m a.s.l.), cover total (\%), cover $\mathrm{E}_{1}$ and $\mathrm{E}_{\mathrm{O}}(\%)$, specific locality:

$521010012018450 \quad 3020$ Šajdíkove Humence, field near railway

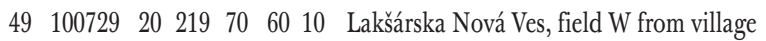

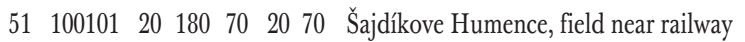
$44 \quad 100713 \quad 2020050 \quad 50 \quad 0 \quad$ Lakšárska Nová Ves, field towards Šišoláky

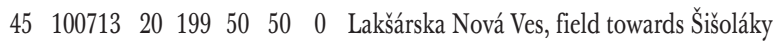

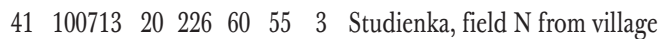

$431007132020360 \quad 60 \quad 3 \quad$ Studienka, (Čechovec $198 \mathrm{~m}$ ), aband. field $42100713201995050 \quad 1$ Studienka, (Čechovec $198 \mathrm{~m}$ ), aband. field $\begin{array}{llllllll}48 & 100729 & 20 & 165 & 50 & 50 & 2 & \text { Borský Sv. Jur, towards Tomky settlement }\end{array}$

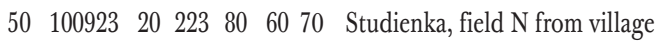

Column C, 7 rels. (11-17) made by Lájer 2004 (orig. tab./rel.: 1/1-7, during 2000-2001 in BolsőSomogy in Hungary). Column D, 16 rels., 5 rels, Koubková 2007 (orig. tab./rel.: 1/4, 8, 29, 58, 59) surroundings Bzenec in Moravia) + 11 rels. made by author - number in table, date (yymmdd), plot $\left(\mathrm{m}^{2}\right)$, altitude (m a.s.l.), cover total (\%), cover $\mathrm{E}_{1}$ and $\mathrm{E}_{\mathrm{O}}(\%)$, specific locality: $\begin{array}{lllllll}32 & 960811 & 10 & 190 & 75 & 50 & 50\end{array}$ Malacky, border of military range $\begin{array}{llllllll}33 & 010630 & 25 & 192 & 70 & 60 & 50 & \text { Malacky, border of military range }\end{array}$

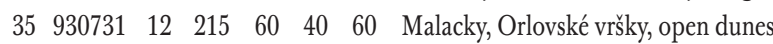

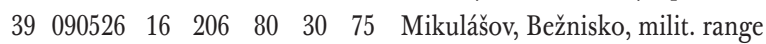
$\begin{array}{llllllll}37 & 080516 & 7 & 196 & 80 & 75 & 10 & \text { Malacky, Krížnica, air range }\end{array}$

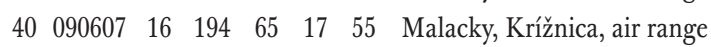
$\begin{array}{llllllll}34 & 020630 & 25 & 190 & 75 & 60 & 40 & \text { Malacky, border of military range }\end{array}$

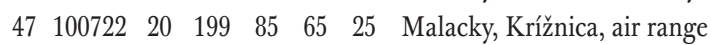
$\begin{array}{llllllll}46 & 100722 & 20 & 200 & 80 & 45 & 70 & \text { Malacky, Krížnica, air range }\end{array}$ $\begin{array}{llllllll}38 & 090601 & 16 & 195 & 90 & 40 & 90 & \text { Malacky, border of military range }\end{array}$ $\begin{array}{llllllll}36 & 090526 & 16 & 169 & 90 & 20 & 80 & \text { Mikulášov, Bežnisko, milit. range }\end{array}$

Column E, 10 rels., 5 rels. (1-10), made by Koubková 2007 (orig. tab./rel.: 1/1, 2, 27, 62, 78), surroundings Bzenec and Hodonín in Moravia); 5 rels. (18-22) made by Hršak 2004, orig. tab./ rel.: 1/6, 4, 9, 13, 17), all from Đurdevac Sand Botanical Reservation in Croatia.
Received 16. 5. 2011 Revision received 14. 10. 2011 Accepted 31. 10. 2011 


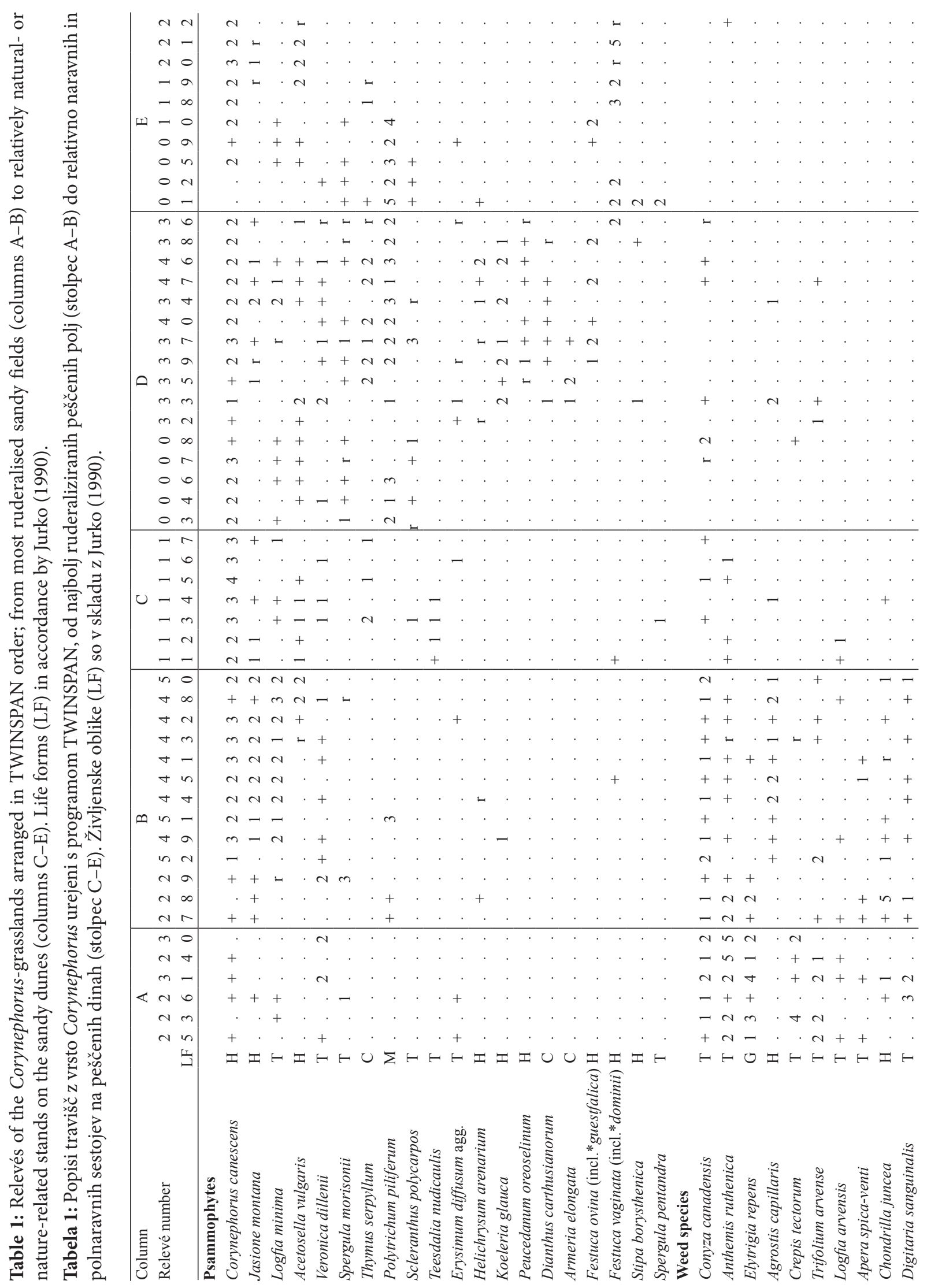



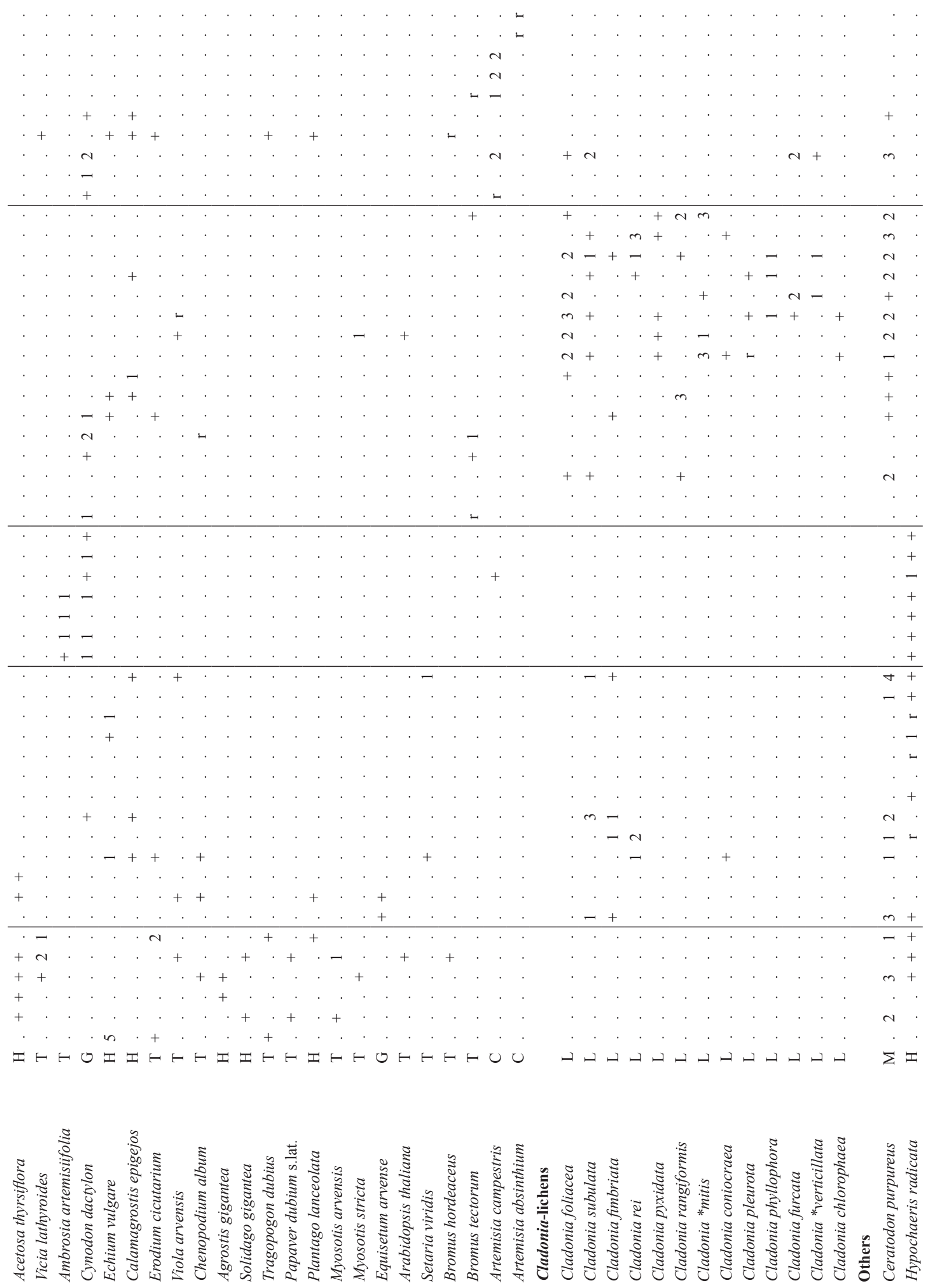


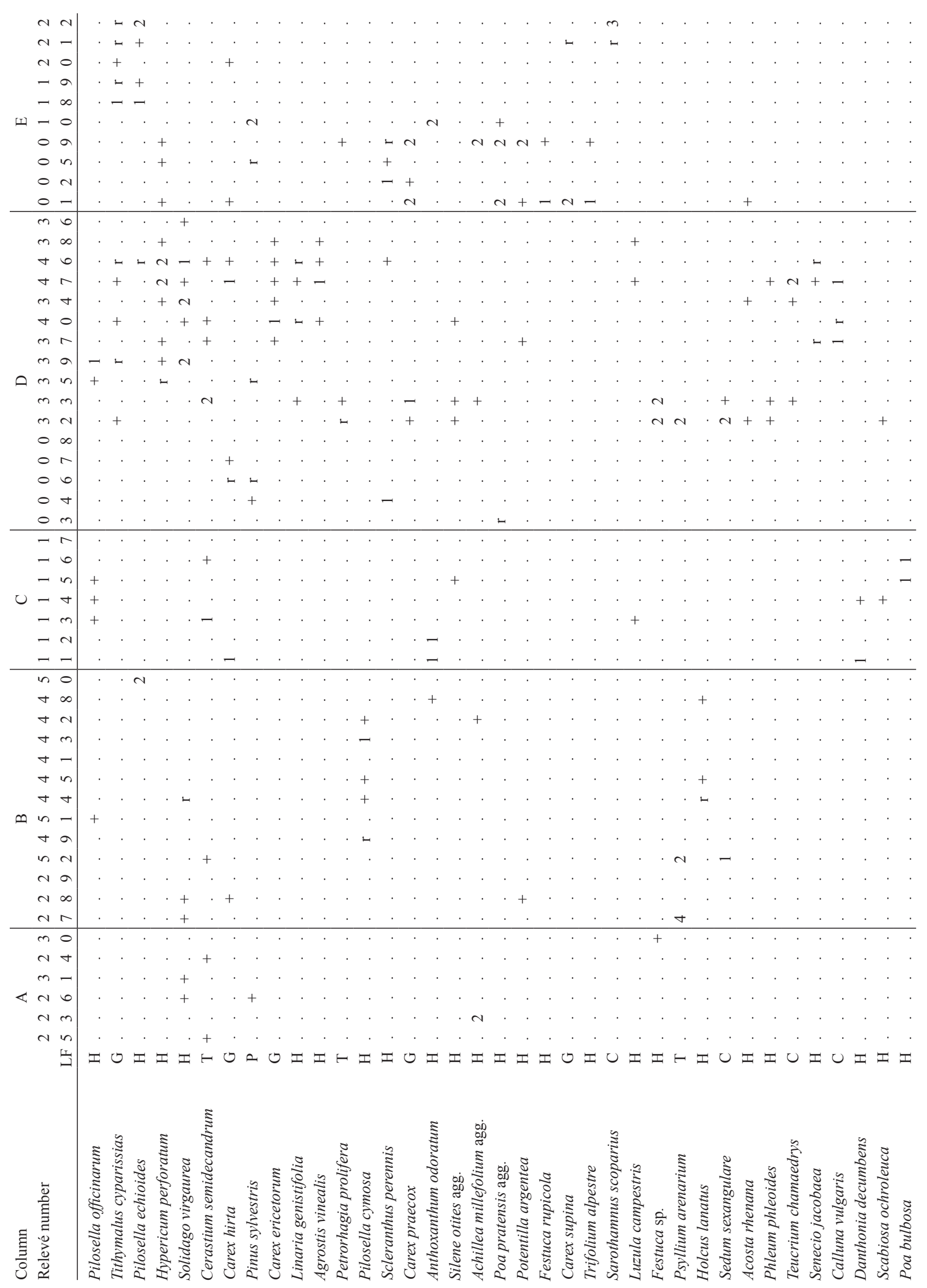




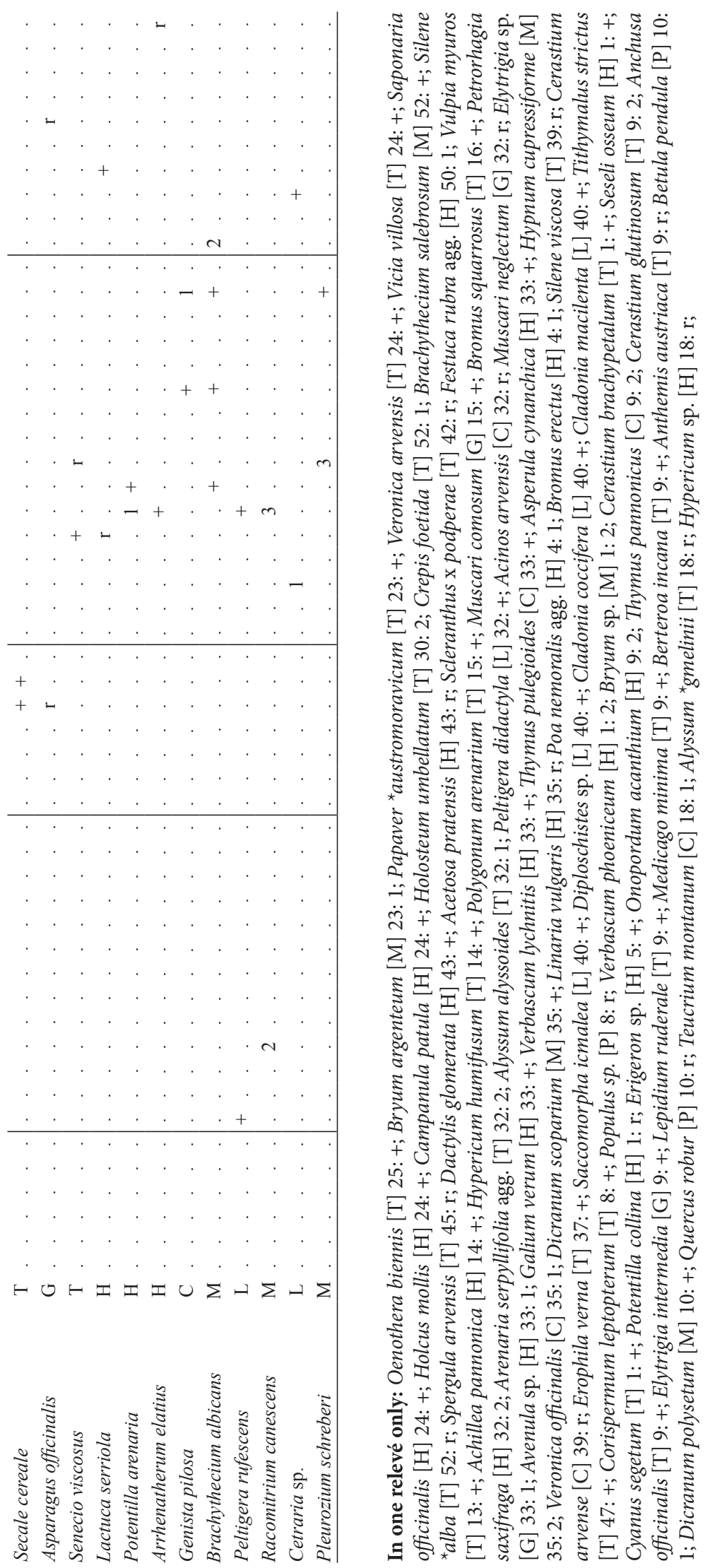

